\title{
Wnt/ $\beta$-catenin/Lef-1 signaling in the uterus and its implications in uterine gland formation and cancer development
}

\author{
Dawne N. Shelton, PhD, ${ }^{1,2}$ Michael J. Goodheart, MD ${ }^{1,2}$ \\ Key Words: beta catenin, cancer, lymphoid enhancer-binding factor 1, neoplasms, uterus, Wnt \\ proteins
}

\begin{abstract}
:
Wnt/b-catenin signaling appears to be important in a multitude of cancers. This review article details current knowledge of the Wnt/b-catenin/Lef1 pathway in generalized gland regulation and formation in addition to endometrial cancer. Wnt signaling is critical for the development of the female urogenital system, in particular mullerian duct formation. Dysregulation of this signaling pathway at multiple nodes has been observed in numerous tumor types, including endometrial cancer. In particular, nuclear accumulation of b-catenin correlates with tumor severity. As such, therapeutic modulation of Wnt signaling represents an emerging avenue for the treatment of cancers that rely on this pathway.
\end{abstract}

${ }^{1}$ The Department of Obstetrics and Gynecology, The Carver College of Medicine, The University of lowa, lowa City, lowa, USA

${ }^{2}$ Holden Comprehensive Cancer Center, The Carver College of Medicine, The University of lowa, lowa City, lowa, USA

\section{Macro Overview of the Uterus}

The mammalian uterus is a complex reproductive organ whose primary purpose is to support the implanted embryo/fetus throughout gestation. It undergoes four main developmental programs over the course of a lifetime. The first program establishes the simple uterine tube. In mice this tube forms in the absence of estrogen receptors (ER) ${ }^{1}$ or progesterone receptors (PR), ${ }^{2}$ indicating that the early program acts independently of the steroid hormones estradiol or progesterone. The second program begins with the onset of puberty, as the endometrium undergoes cyclical waves of proliferation, differentiation, and, barring implantation, regression; this cyclic wave is termed the menstrual cycle in primates and estrous cycle in nonprimate species. In preparation for implantation of the embryo into the uterine lining, the third program begins with decidualization induced by progesterone signaling. ${ }^{3}$ This process causes increased glandular cell secretions, vascular remodeling,

Please cite this paper as: Shelton, DN, Goodheart MJ. Wnt/ß-catenin/Lef-1 signaling in the uterus and its implications in uterine gland formation and cancer development. Proc Obstet Gynecol. 2011 July;2(1):Article 16 [11 p.]. Available from: http://ir.uiowa.edu/pog/. Free full text article.

Corresponding author: Michael J. Goodheart, M.D. Department of Obstetrics and Gynecology, University of lowa, 4631 JCP, 200 Hawkins Drive, lowa City, IA 52242. Telephone (319)356-2015. michaelgoodheart@uiowa.edu

This is an Open Access article distributed under the terms of the Creative Commons Attribution 3.0 Unported License (http://creativecommons.org/licenses/by/3.0), which permits unrestricted use, distribution, and reproduction in any medium, provided the original work is properly cited. 
and stromal storage of glycogen. These changes support the developing embryo until the placenta matures as well as modulate maternal-fetal communications. Finally, as the ovaries stop producing estradiol, testosterone, and progesterone, the uterus regresses into a state of atrophy and a woman enters menopause. While the roles of estrogen, progesterone, and testosterone in these programs have been widely studied, the molecular mechanisms determining initial development, adenogenesis, and regeneration of the endometrium are still unclear.

\section{Molecular/histological description of the uterus and stages of development}

The uterus consists of a highly regenerative endometrium and a muscular outer myometrium. ${ }^{4}$ The endometrium is made up of the luminal epithelium and tree-like endometrial glands, which are embedded within a fibroblast-like stroma. In humans the endometrium is further divided into the basalis layer of tissue and epithelial glands. The Basalis layer consists of a dense stroma near the myometrium and is interspersed with epithelial glands, in which reside the putative adult stem cells needed to regenerate the endometrium following menses. ${ }^{5,6,7}$ These stem cells reepithelialize the lumen, and then expand the stromal and glandular portions to reform the functionalis layer. Though histologically distinct in humans, these layers appear less well defined in mice. However, studies examining label-retaining cells (LRCs) in the murine endometrium following decidualization and endometrial breakdown during the estrous cycle indicate the existence of putative stem cells near the myometrial layer in the remnants of endometrial glands. ${ }^{8}$

The uterus is derived from the sexually undistinguished bilateral embryonic Mullerian ducts, which are formed during invagination of the coelomic epithelium into tubular stoma. $^{9}$ Expression of the maledetermining factor, SRY, stimulates expression of antiMullerian hormone $(\mathrm{AMH})$, which induces regression of the Mullerian duct in males. Without SRY and $\mathrm{AMH}$, the Mullerian ducts continue developing and eventually become the female internal reproductive organs. ${ }^{10}$ As the ducts proliferate and expand caudally, the Mullerian ducts fuse at the midline, thus forming the uterus. In primates this fusion is complete and yields a single uterus, whereas in most nonprimate mammals incomplete fusion occurs and leads to the presence of two uterine horns. While development of the uterus is wellunderstood at the anatomical level, we are still unraveling the cellular pathways that mediate these distinct stages of development. However, several pieces of data have demonstrated a critical role for the Wnt signaling pathway in formation of the uterus. 


\section{Indications that the Wnt pathway is critical to uterine development}

Mouse knockout studies demonstrate the importance of the Wnt signaling pathway in reproductive organ development. Mullerian duct formation requires Wnt4 and Wnt9b expression, as deficiency of either of these genes prevents formation of the female urogenital system. ${ }^{11,12}$ At the cellular level, Wnt7a is expressed within the luminal cells of the early developing uterus and is required for gland formation. ${ }^{13,14} \mathrm{Wnt5a}$ is expressed within the uterine stroma and also required for adenogenesis. ${ }^{15}$ Mice engineered to express activated beta-catenin in the endometrium develop proliferative hyperplasias, ${ }^{16}$ while expression in the myometrium leads to uterine fibroids. ${ }^{17}$ Wnt4 is also required for the decidualization process following implantation, as demonstrated by conditional knockout of Wnt4 in PR-expressing endometrial cells.$^{18}$ Aberrations in Wnt signaling are associated with infertility, endometriosis, endometrial cancer and gestational diseases, ${ }^{19}$ underscoring the importance of this pathway. Further, there are indications that the Wnt pathway is required to mediate the actions of estrogen signaling ${ }^{20}$ whereas progesterone inhibits the Wnt pathway, ${ }^{21}$ exemplifying the intrinsic dance of steroid hormonal signaling and Wnt-mediated proliferation and differentiation.

\section{Wnt pathway overview}

The Wnt pathway was initially discovered via two parallel areas of research, early development and tumorigenesis. In Drosophila, mutations in the Wingless $(\mathrm{Wg})$ gene led to wingless flies and other early developmental abnormalities. ${ }^{22}$ Studies involving the int gene in mice revealed the role of this protein in tumorigenesis. ${ }^{23}$ Many years later homology studies indicated that the $W g$ and int genes belong to the same evolutionary family, and the canonical Wnt pathway was born. ${ }^{24}$ Wnt is now known to be a secreted ligand that binds to the Frizzled (Fz) receptor family of nearby cells, often in a gradient fashion, to regulate cell differentiation and proliferation in early development. ${ }^{25,26,27} \mathrm{Fz}$ then activates the Dishevelled (Dsh) protein, which causes the disassociation of the " $\beta$-catenin destruction complex." $28,29,30,31,32$ This complex of proteins consists of the adenomatous polyposis coli gene (APC), axin, and GSK3, which induce degradation of $\beta$-catenin through proteolysis. In response to a Wnt activating signal, $\beta$-catenin levels rise, and then $\beta$-catenin translocates to the cell nucleus and binds to transcription factors of the TCF/LEF family. ${ }^{33,34,35}$ Thus, $\beta$ catenin serves as transcriptional activator for downstream target genes. The list of Wnt signaling targets include cyclin $\mathrm{D}$, a regulator of cell cycle progression, ${ }^{36,37}$ c-myc, a strong oncogene that recruits histone acetyltransferases (HATs), which remodel the chromatin and allow for increased transcription, ${ }^{38}$ 
and several matrix metalloproteins (MMPs), which are involved in cell migration and differentiation. ${ }^{39,40,41}$ By controlling expression of multiple genes that mediate in a plethora of cellular events, the Wnt pathway is a central regulator of basic cellular processes.

In addition to the canonical Wnt pathway, several studies have indicated Wnt signaling can be propagated through alternate, noncanonical pathways, including Wnts 4, 5a and Wnt 11. For example, in the planar cell polarity pathway (PCP), Wnts maintain signals though Fzs to activate Dsh, but Dsh then binds to other proteins of the Rac/Rho/Rock/JNK pathway that regulate actin remodeling of the cytoskeleton and cell migration. Yet another non-canonical pathway is the Wnt/calcium pathway, where Wnts interact with Fzs and activate Dsh in combination with coupled Gproteins. Downstream signaling through the G-proteins eventually leads to the release of intracellular calcium from the endoplasmic reticulum. Wnt/Ca ${ }^{2+}$ signaling is believed to counter classical Wnt signaling, but further research is needed to understand the precise mechanism.

\section{Wnt pathway and cancer}

Since the initial finding that the mutations in the int gene results in formation of mammary tumors in mice, mutations in the various components of the Wnt pathway have been documented in many human cancers. One of the best- studied mutations is in the APC gene, which was originally identified by linkage studies performed on patients with hereditary adenomatous polyposis coli. Patients with mutations in APC develop numerous intestinal and colonic polyps very early in life and have a near $100 \%$ penetrance of colorectal cancer by their early $40 \mathrm{~s} .{ }^{42}$ Hereditary mutations in APC account for only $\sim 1 \%$ of all colorectal cancers, but, when combined with sporadic mutations, account for $>80 \%$, indicating the importance of the Wnt pathway in colorectal cancer. Further, mutations or alterations in the Wnt pathway, most specifically $\beta$-catenin, have been found in cancers of the breast, colon, ovaries, uterus, blood, liver, pancreas, and skin, among others. $^{43,44}$

\section{Wnts in endometrial cancer}

Endometrial carcinoma is the most common gynecologic malignancy and ranks second as a cause of gynecologic cancer mortality in the United States; in 2010, the American Cancer Society predicted 43,470 new cases and 7,950 deaths in that year alone. ${ }^{45}$ Most endometrial carcinomas arise from the glands of the endometrium (adenocarcinomas), and the remainder are derived from the supporting stroma (sarcomas). Endometrial carcinomas are divided into two broad categories of tumors based on their etiology. ${ }^{46}$ Type I endometrioid endometrial carcinomas (EEC) are typified by a hyperestrogenic state, general low 
grade, and low stage. They are typically responsive to progesterone treatment and express estrogen and progesterone receptors. They also occur in pre- and perimenopausal women with a generally high BMI and account for roughly $80 \%$ of endometrial cancers. Luckily, with surgical, hormone, and/or chemotherapeutic treatments, they are roughly $85 \%$ curable at the 5 year survival mark. Type II nonendometrioid endometrial carcinomas (NEEC) do not correlate with a hyperestrogenic state and occur in postmenopausal women with atrophic endometrium. These tumors are generally high grade, poorly differentiated, and very aggressive with poor outcomes. They generally do not express ER or $P R$ and are not responsive to hormonal treatment. While it is useful to divide the tumors into broad categories, it should be noted that there is overlap between the two types. For example, some subsets of endometrioid tumors progress to high grade and poor prognosis, while others exhibit mixed characteristics of both. Therefore, an understanding of the molecular profile of the tumors may be more informative in terms of guiding treatment for individual endometrial tumors, regardless of segregation into Type I or II status.

As expected, the two types of endometrial cancer also have differing molecular dysregulations. The two predominant alternations noted in most Type I endometriod cancers are changes in the tumor suppressor PTEN, a protein and lipid phosphatase, and elevated levels of $\beta$-catenin. Loss of PTEN results in abrogation of cell cycle checkpoint control and up-regulation of antiapoptotic pathways. PTEN mutations are reported in $25-83 \%$ of endometrioid tumors, whereas these occur in less than $10 \%$ of Type II NEECs. ${ }^{47}$ Conditional knockout of PTEN in ER-expressing cells results in endometrial hyperplasia as early as 10 days postnatally, with progression to carcinoma by one month. ${ }^{48}$ These data indicate that loss of PTEN specifically results in endometrial carcinoma with 100\% penetrance. In contrast to Type I tumors with mutant PTEN, the most common alterations noted in Type II tumors are mutations in the tumor suppressor P53. ${ }^{49}$ Occasionally mutations in P53 are observed in grade 3 Type I endometriod tumors, while $90 \%$ of NEECs exhibit P53 mutations. Of particular interest, P53 mutations often occur in the absence of hyperplasias again indicating hormone indifference. ${ }^{50}$

The other predominant alteration noted in Type I endometrial tumors is nuclear accumulation of $\beta$-catenin (e.g., $\quad 13-69 \%$ of cases of endometrioid endometrial carcinoma), but only a few studies have examined the role of Wnt signaling in its etiology. Among these, one study by Fukuchi et al. ${ }^{51}$ assessed endometrial tumors for $\beta$ catenin mutations in exon 3 , the site of regulatory phosphorylation by GSK3 $\beta$. Mutations in this domain result in constitutive $\beta$-catenin nuclear accumulation and corresponding transcriptional activity and have been associated with many 
solid tumors. Of the 76 tumors examined, approximately $13 \%$ had mutations within this domain, and $38 \%$ expressed $\beta$-catenin at high levels. ${ }^{51}$ Similar to studies of ovarian and colorectal cancers, a relationship between nuclear $\beta$ catenin expression and stage, grade, and prognosis have been found in endometrial cancer. ${ }^{52,53,54,55,56}$ Other studies have shown that, whereas overall $\beta$-catenin levels correlate negatively with cancer grade, nuclear accumulation in cells at the invasive front of the tumor correlates positively with tumor stage, grade, and poor prognoses. ${ }^{57,58,59}$ In one study, transgenic mice in which activated $\beta$-catenin was expressed specifically in the uterus exhibited high levels of nuclear $\beta$-catenin accumulation, increased expression of c-myc and cyclin D1, increased glandular proliferation, and extensive hyperplasia - but, strikingly, no cancer within the first year of life. ${ }^{16}$ Thus, these data suggest that elevated nuclear $\beta$-catenin alone is not tumorigenic.

Another study examined the role of Lef1 in endometrial cancer, a downstream target of $\beta$-catenin signaling (Shelton and Goodheart, submitted Clinical Cancer Research). Aberrant overexpression of the Wnt-pathway target gene LEF1 has been detected in several cancers, principally colon, leukemia, melanoma, and pancreatic. In unpublished data, we found that expression of Lef1 is also elevated in human endometrial tumors regardless of histological subtype and in non-cancerous proliferative endometrium but not in inactive endometrium. Lef1 mRNA was expressed at higher levels in EEC than in NEEC, and was expressed at higher levels in tumors of grades 1 and 2 than in those of grade 3 . Importantly, Lef1 expression was higher in cohorts with good prognosis. Collectively, these data suggest a role for Lef1 in tumorigenesis but not metastasis.

In addition to Lef1 and $\beta$-catenin, we have observed significant dysregulation of several components of the Wnt pathway (Goodheart, et al, unpublished observations). Taken together with the current understanding of $\beta$-catenin and Lef1 in endometrial cancer, these data underscore the importance of Wnt signaling in not only endometrial gland formation, but also in endometrial cancer formation.

\section{Conclusions}

Wnt/ $\beta$-catenin signaling appears to be important in a multitude of cancers, including endometrial cancer. Our data, detailed above, supports a role for the Wnt/ $\beta$ catenin/Lef1 pathway involvement in endometrial cancer in addition to generalized gland regulation and formation (submitted Neoplasia). Many commercial pharmaceutical companies are developing targeted inhibitors of Wnt signaling, and currently there are compounds available for use in cell culture and animal experiments (e.g., XAV939 www.reagentsdirect.com). Further investigation into the complex interactions between $\mathrm{Wnt} / \beta$-catenin 
signaling and endometrial gland formation and cancer appears to be warranted in order to selectively inhibit pathways that are integral for endometrial cancer development.

\section{References}

1. Lubahn DB, Moyer JS, Golding TS, Couse JF, Korach KS, Smithies O. Alteration of reproductive function but not prenatal sexual development after insertional disruption of the mouse estrogen receptor gene. Proc Natl Acad Sci U S A. 1993 Dec 1;90(23):11162-6.

2. Lydon JP, DeMayo FJ, Funk CR, Mani SK, Hughes AR, Montgomery CA Jr, Shyamala G, Conneely OM, O'Malley BW. Mice lacking progesterone receptor exhibit pleiotropic reproductive abnormalities. Genes Dev. 1995 Sep 15;9(18):2266-78.

3. Gellersen B, Brosens IA, Brosens JJ. Decidualization of the human endometrium: mechanisms, functions, and clinical perspectives. Semin Reprod Med. 2007 Nov;25(6):445-53.

4. Kurita T, Lee K, Saunders PT, Cooke PS, Taylor JA, Lubahn DB, Zhao C, Mäkelä S, Gustafsson JA, Dahiya R, Cunha GR. Regulation of progesterone receptors and decidualization in uterine stroma of the estrogen receptor-alpha knockout mouse. Biol Reprod. 2001 Jan;64(1):272-83.

5. Kunz G, Leyendecker G. Uterine peristaltic activity during the menstrual cycle: characterization, regulation, function and dysfunction. Reprod Biomed Online. 2002;4 Suppl 3:5-9.
6. Padykula HA, Coles LG, Okulicz WC, Rapaport SI, McCracken JA, King NW Jr, Longcope C, Kaiserman-Abramof IR. The basalis of the primate endometrium: a bifunctional germinal compartment. Biol Reprod. 1989 Mar;40(3):68190.

7. Gargett CE. Uterine stem cells: what is the evidence? Hum Reprod Update. 2007 Jan-Feb;13(1):87101. Epub 2006 Sep 7.

8. Kaitu'u-Lino TJ, Ye L, Gargett CE. Reepithelialization of the uterine surface arises from endometrial glands: evidence from a functional mouse model of breakdown and repair. Endocrinology. 2010 Jul;151(7):3386-95. Epub 2010 May 5.

9. Jacob $\mathrm{M}$, Konrad $\mathrm{K}$, Jacob $\mathrm{HJ}$. Early development of the müllerian duct in avian embryos with reference to the human. An ultrastructural and immunohistochemical study. Cells Tissues Organs. 1999;164(2):63-81

10. Teixeira J, Maheswaran S, Donahoe PK. Müllerian inhibiting substance: an instructive developmental hormone with diagnostic and possible therapeutic applications. Endocr Rev. 2001 Oct;22(5):657-74.

11. Vainio $S$, Heikkilä $M$, Kispert $A$, Chin N, McMahon AP. Female development in mammals is regulated by Wnt-4 signalling. Nature. 1999 Feb 4;397(6718):4059.

12. Carroll TJ, Park JS, Hayashi S, Majumdar A, McMahon AP. Wnt9b plays a central role in the regulation of mesenchymal to epithelial transitions underlying organogenesis of the mammalian urogenital system. Dev Cell. 2005 Aug;9(2):283-92. 
13. Miller C, Sassoon DA. Wnt-7a maintains appropriate uterine patterning during the development of the mouse female reproductive tract. Development. 1998 Aug;125(16):3201-11.

14. Parr BA, McMahon AP. Sexually dimorphic development of the mammalian reproductive tract requires Wnt-7a. Nature. 1998 Oct 15;395(6703):707-10.

15. Mericskay M, Kitajewski J, Sassoon D. Wnt5a is required for proper epithelial-mesenchymal interactions in the uterus. Development. 2004 May;131(9):2061-72. Epub 2004 Apr 8.

16. Jeong JW, Lee HS, Franco HL, Broaddus RR, Taketo MM, Tsai SY, Lydon JP, DeMayo FJ. beta-catenin mediates glandular formation and dysregulation of beta catenin induces hyperplasia formation in the murine uterus. Oncogene. 2009 Jan 8;28(1):31-40. Epub 2008 Sep 22.

17. Tanwar PS, Lee HJ, Zhang L, Zukerberg LR, Taketo MM, Rueda BR, Teixeira JM. Constitutive activation of Beta-catenin in uterine stroma and smooth muscle leads to the development of mesenchymal tumors in mice. Biol Reprod. 2009 Sep;81(3):545-52. Epub 2009 Apr 29.

18. Franco HL, Dai D, Lee KY, Rubel CA, Roop D, Boerboom D, Jeong JW, Lydon JP, Bagchi IC, Bagchi MK, DeMayo FJ. WNT4 is a key regulator of normal postnatal uterine development and progesterone signaling during embryo implantation and decidualization in the mouse. FASEB J. 2011 Apr;25(4):1176-87. Epub 2010 Dec 16.
19. Sonderegger S, Pollheimer J, Knöfler M. Wnt signalling in implantation, decidualisation and placental differentiation--review. Placenta. 2010 Oct;31(10):839-47. Epub 2010 Aug 15.

20. Ray S, Xu F, Wang H, Das SK. Cooperative control via Iymphoid enhancer factor $1 / \mathrm{T}$ cell factor 3 and estrogen receptor-alpha for uterine gene regulation by estrogen. Mol Endocrinol. 2008 May;22(5):112540. Epub 2008 Jan 17.

21. Wang $\mathrm{Y}$, van der Zee $\mathrm{M}$, Fodde $\mathrm{R}$, Blok LJ. Wnt/B-catenin and sex hormone signaling in endometrial homeostasis and cancer. Oncotarget. 2010 Nov;1(7):674-84.

22. Sharma RP, Chopra VL. Effect of the Wingless (wg1) mutation on wing and haltere development in Drosophila melanogaster. Dev Biol. 1976 Feb;48(2):461 5.

23. Nusse R, Varmus HE. Many tumors induced by the mouse mammary tumor virus contain a provirus integrated in the same region of the host genome. Cell. 1982 Nov;31(1):99-109.

24. Rijsewijk $F$, Schuermann $M$, Wagenaar E, Parren P, Weigel D, Nusse R. The Drosophila homolog of the mouse mammary oncogene int-1 is identical to the segment polarity gene wingless. Cell. 1987 Aug 14;50(4):649-57.

25. Bhanot $P$, Brink $M$, Samos $C H$, Hsieh JC, Wang Y, Macke JP, Andrew D, Nathans J, Nusse R. A new member of the frizzled family from Drosophila functions as a Wingless receptor. Nature. $1996 \mathrm{Jul}$ 18;382(6588):225-30. 
26. Yang-Snyder J, Miller JR, Brown JD, Lai CJ, Moon RT. A frizzled homolog functions in a vertebrate Wnt signaling pathway. Curr Biol. 1996 Oct 1;6(10):1302-6.

27. Finch PW, He X, Kelley MJ, Uren A, Schaudies RP, Popescu NC, Rudikoff S, Aaronson SA, Varmus HE, Rubin JS. Purification and molecular cloning of a secreted, Frizzled-related antagonist of Wnt action. Proc Natl Acad Sci U S A. 1997 Jun 24;94(13):6770-5.

28. Itoh K, Krupnik VE, Sokol SY. Axis determination in Xenopus involves biochemical interactions of axin, glycogen synthase kinase 3 and beta catenin. Curr Biol. 1998 May 7;8(10):591-4.

29. Kishida S, Yamamoto $\mathrm{H}$, Hino $\mathrm{S}$, Ikeda S, Kishida M, Kikuchi A. DIX domains of Dvl and axin are necessary for protein interactions and their ability to regulate betacatenin stability. Mol Cell Biol. 1999 Jun;19(6):4414-22.

30. Lee JS, Ishimoto A, Yanagawa S. Characterization of mouse dishevelled (Dvl) proteins in Wnt/Wingless signaling pathway. J Biol Chem. 1999 Jul 23;274(30):21464-70.

31. Peters JM, McKay RM, McKay JP, Graff JM. Casein kinase I transduces Wnt signals. Nature. 1999 Sep 23;401(6751):345-50.

32. Smalley MJ, Sara E, Paterson H, Naylor S, Cook D, Jayatilake $\mathrm{H}$, Fryer LG, Hutchinson L, Fry MJ, Dale TC. Interaction of axin and Dvl2 proteins regulates Dvl-2stimulated TCF-dependent transcription. EMBO J. 1999 May 17;18(10):2823-35.

33. Behrens J, von Kries JP, Kühl M, Bruhn L, Wedlich D, Grosschedl R, Birchmeier W. Functional interaction of beta-catenin with the transcription factor LEF 1. Nature. 1996 Aug 15;382(6592):638-42.

34. Molenaar $M$, van de Wetering $M$, Oosterwegel M, Peterson-Maduro J, Godsave S, Korinek V, Roose J, Destrée O, Clevers H. XTcf-3 transcription factor mediates betacatenin-induced axis formation in Xenopus embryos. Cell. 1996 Aug 9;86(3):391-9.

35. Hart M, Concordet JP, Lassot I, Albert I, del los Santos R, Durand H, Perret C, Rubinfeld B, Margottin F, Benarous R, Polakis P. The F-box protein beta $\mathrm{TrCP}$ associates with phosphorylated beta-catenin and regulates its activity in the cell. Curr Biol. 1999 Feb 25;9(4):207-10.

36. Shtutman $M$, Zhurinsky J, Oren $M$, Levina $E$, Ben-Ze'ev A. PML is a target gene of beta-catenin and plakoglobin, and coactivates betacatenin-mediated transcription. Cancer Res. 2002 Oct 15;62(20):5947-54.

37. Cole AM, Myant K, Reed KR, Ridgway RA, Athineos $D$, Van den Brink GR, Muncan V, Clevers H, Clarke AR, Sicinski P, Sansom OJ. Cyclin D2-cyclin-dependent kinase $4 / 6$ is required for efficient proliferation and tumorigenesis following Apc loss. Cancer Res. 2010 Oct 15;70(20):8149-58. Epub 2010 Aug 24.

38. Jung $\mathrm{HC}$, Kim K. Identification of MYCBP as a beta-catenin/LEF-1 target using DNA microarray analysis. Life Sci. 2005 Jul 29;77(11):1249-62.

39. Brabletz $T$, Jung $A$, Dag $S$, Hlubek F, Kirchner T. beta-catenin regulates the expression of the matrix metalloproteinase-7 in human colorectal cancer. Am J Pathol. 1999 Oct;155(4):1033-8. 
40. Ingraham CA, Park GC, Makarenkova HP, Crossin KL. Matrix metalloproteinase (MMP)-9 induced by Wnt signaling increases the proliferation and migration of embryonic neural stem cells at low O2 levels. J Biol Chem. 2011 May 20;286(20):17649-57. Epub 2011 Apr 1.

41. Kamino $M$, Kishida $M$, Kibe $T$, Ikoma $\mathrm{K}$, lijima $\mathrm{M}$, Hirano $\mathrm{H}$, Tokudome M, Chen L, Koriyama C, Yamada K, Arita K, Kishida S. Wnt$5 a$ signaling is correlated with infiltrative activity in human glioma by inducing cellular migration and MMP 2. Cancer Sci. 2011 Mar;102(3):540-8. doi: 10.1111/j.1349-7006.2010.01815.x. Epub 2011 Jan 10.

42. Fearnhead NS, Britton MP, Bodmer WF. The ABC of APC. Hum Mol Genet. 2001 Apr;10(7):721-33.

43. Polakis P. Wnt signaling and cancer. Genes Dev. 2000 Aug 1;14(15):1837-51.

44. Cowling $\mathrm{VH}$, Cole MD. Turning the tables: Myc activates Wnt in breast cancer. Cell Cycle. 2007 Nov 1;6(21):2625-7. Epub 2007 Aug 13.

\section{American Cancer Society [Internet]. Available from: http://www.cancer.org/.}

46. Bokhman JV. Two pathogenetic types of endometrial carcinoma. Gynecol Oncol. 1983 Feb;15(1):107.

47. Bansal N, Yendluri V, Wenham RM. The molecular biology of endometrial cancers and the implications for pathogenesis, classification, and targeted therapies. Cancer Control. 2009 Jan;16(1):8-13.
48. Daikoku T, Hirota Y, Tranguch S, Joshi AR, DeMayo FJ, Lydon JP, Ellenson LH, Dey SK. Conditional loss of uterine Pten unfailingly and rapidly induces endometrial cancer in mice. Cancer Res. 2008 Jul 15;68(14):5619-27.

49. Tashiro $H$, Isacson $C$, Levine $R$, Kurman RJ, Cho KR, Hedrick L. p53 gene mutations are common in uterine serous carcinoma and occur early in their pathogenesis. Am J Pathol. 1997 Jan;150(1):177-85.

50. Lax SF, Kendall B, Tashiro H, Slebos RJ, Hedrick L. The frequency of p53, K-ras mutations, and microsatellite instability differs in uterine endometrioid and serous carcinoma: evidence of distinct molecular genetic pathways. Cancer. 2000 Feb 15;88(4):814-24.

51. Fukuchi T, Sakamoto M, Tsuda H, Maruyama K, Nozawa S, Hirohashi $\mathrm{S}$. Beta-catenin mutation in carcinoma of the uterine endometrium. Cancer Res. 1998 Aug 15;58(16):3526-8.

52. Baldus SE, Mönig SP, Huxel S, Landsberg S, Hanisch FG, Engelmann K, Schneider PM, Thiele J, Hölscher AH, Dienes HP. MUC1 and nuclear beta-catenin are coexpressed at the invasion front of colorectal carcinomas and are both correlated with tumor prognosis. Clin Cancer Res. 2004 Apr 15;10(8):2790-6.

53. Gamallo C, Palacios J, Moreno G, Calvo de Mora J, Suárez A, Armas A. beta-catenin expression pattern in stage I and II ovarian carcinomas : relationship with beta-catenin gene mutations, clinicopathological features, and clinical outcome. Am J Pathol. 1999 Aug;155(2):527-36. 
54. Horst D, Kriegl L, Engel J, Jung A, Kirchner T. CD133 and nuclear beta-catenin: the marker combination to detect high risk cases of low stage colorectal cancer. Eur J Cancer. 2009 Jul;45(11):2034-40. Epub 2009 May 4.

55. Horst D, Reu S, Kriegl L, Engel J, Kirchner T, Jung $A$. The intratumoral distribution of nuclear beta-catenin is a prognostic marker in colon cancer. Cancer. 2009 May 15;115(10):2063-70.

56. Moreno-Bueno G, Gamallo C, Pérez-Gallego L, de Mora JC, Suárez $\mathrm{A}$, Palacios J. beta-Catenin expression pattern, beta-catenin gene mutations, and microsatellite instability in endometrioid ovarian carcinomas and synchronous endometrial carcinomas. Diagn Mol Pathol. 2001 Jun;10(2):116-22.
57. Nei $H$, Saito T, Yamasaki $H$, Mizumoto $\mathrm{H}$, Ito E, Kudo R. Nuclear localization of beta-catenin in normal and carcinogenic endometrium. Mol Carcinog. 1999 Jul;25(3):207-18.

58. Saegusa $M$, Hashimura $M$, Yoshida T, Okayasu I. beta- Catenin mutations and aberrant nuclear expression during endometrial tumorigenesis. $\mathrm{Br} \mathrm{J}$ Cancer. 2001 Jan;84(2):209-17.

59. Saegusa M, Okayasu I. Frequent nuclear beta-catenin accumulation and associated mutations in endometrioid-type endometrial and ovarian carcinomas with squamous differentiation. J Pathol. 2001 May;194(1):59-67. 